\title{
O DANO AO PROJETO DE VIDA E SUA AUTONOMIA EM FACE DO DANO MORAL
}

\section{THE DAMAGE TO LIFE PROJECT AND YOUR AUTONOMY IN FACE OF MORAL DAMAGES}

\section{RESUMO}

\author{
${ }^{1}$ Carlos Giovani Pinto Portugal \\ ${ }^{2}$ Rosalice Fidalgo Pinheiro
}

O presente trabalho tem por objetivo delinear a autonomia do dano ao projeto de vida em face do dano moral. Parte do paradoxo entre os novos danos e a insuficiência da summa divisio dos danos em patrimoniais e morais. Critica-se a identificação dos danos morais aos extrapatrimonais por parte da doutrina e jurisprudência brasileiras, como um fator de absorção do dano ao projeto de vida pelo dano moral. O reconhecimento conceitual da nova figura segue duas direções: a caracterização do projeto de vida em seu núcleo e a natureza jurídica de dano à pessoa. Para tanto, o trabalho elege como marco teórico o personalismo de Carlos Fernández Sessarego, ao depositar na coexistência do projeto de vida o núcleo do dano à liberdade fenomênica, e na qualificação de dano à pessoa sua natureza jurídica. A perspectiva civil-constitucional também comparece para fundamentar a nova hipótese de dano na agressão ao livre desenvolvimento da personalidade e no respeito e proteção à dignidade da pessoa humana. Utilizando-se do método dedutivo e do procedimento bibliográfico o plano de trabalho divide-se em quatro partes: (i) o projeto de vida o livre desenvolvimento da personalidade; (ii) os novos danos e o dano ao projeto de vida; (iii) a absorção do dano ao projeto de vida pelo dano moral e (iv) o dano ao projeto de vida como dano à pessoa.

Palavras-chave: Dano ao projeto de vida, Dano moral, Direitos fundamentais

\section{ABSTRACT}

This paper aims to outline the autonomy of damage to the life project in the face of moral damage. Part of the paradox between the "further damage" and the insufficiency of "clear distinction" of damage to economic and moral. Criticizes the identification of moral damage to non-economics by the doctrine and Brazilian jurisprudence, as a factor of absorption of the damage to the project of life for moral damage. The conceptual recognition of the new figure follows two directions: the characterization of the life project at its core and the legal nature of damage to the person. For this purpose, the work chooses as theoretical mark personalism of Carlos Fernández Sessarego, when depositing the coexistence of the core life project "damage to the phenomenal freedom", and damage to the person qualifying its legal nature. The civil and constitutional perspective also appears to support the new hypothesis of damage in the aggression to free development of personality and the respect and protection of

human dignity. If using the deductive method and procedure of the bibliographic the work plan is divided into four parts: (i) the life plan the free development of personality; (ii) the news damages and the damage to the life project; (iii) the absorption of the damage to the project of life for moral damage and (iv) the damage to the life project as damage to person.

Keywords: Damage to the life project, Moral damage, Fundamental rights

\footnotetext{
${ }^{1}$ Mestre em Direitos Fundamentais e Democracia pelo Centro Universitário UNIBRASIL, Parana, (Brasil) Email: tutortreinamento@gmail.com

${ }^{2}$ Doutora em Direito pela Universidade Federal do Paraná - UFPR, Paraná, Brasil,Professora Adjunta do Faculdades do Brasil, Paraná, (Brasil).
} 


\section{INTRODUÇÃO}

As transformações vividas pelas sociedades pós-industrializadas levaram à passagem da responsabilidade civil para o direito de danos. Trata-se de uma modificação estrutural que deslocou o centro deste sistema da culpa e do ato ilícito para a pessoa vitimada e o dano injusto. Esse giro conceitual permitiu à civilística brasileira voltar-se para a questão da proliferação dos danos suscetíveis de reparação, delineando-se o fenômeno dos "novos danos".

Esse movimento decorre de uma ampliação do rol de hipóteses de dano moral jurisprudencialmente reconhecidas, em face de uma cláusula aberta de proteção dos direitos da personalidade no direito brasileiro. Este fenômeno expressa a primazia das situações existenciais sobre as patrimoniais, afastando-se a responsabilidade civil dos valores do liberalismo clássico assentados no indivíduo proprietário para depositá-la no valor da pessoa humana, em atenção à inflexão personalista do Direito. Novas categorias encontram lugar, conquistando o reconhecimento conceitual em uma esfera extrapatrimonial, como os danos coletivos, estéticos, à saúde, biológicos, existenciais e o dano ao projeto de vida.

Paradoxalmente, esse movimento é contraditado por uma indefinição acerca da categorização desse novo dano, em face de uma suposta necessidade de subsumi-lo à distinção entre dano patrimonial e dano moral. As escassas menções a seu respeito, por parte da doutrina e da jurisprudência pátrias, convivem com a contestação de sua autonomia. Contudo, o problema proposto por este artigo ultrapassa a mera qualificação deste novo dano à luz de uma "summa divisio" que remonta à separação entre pessoas e coisas. Está em questão a identificação entre dano moral e dano extrapatrimonial por parte da civilística nacional e a consequente absorção do dano ao projeto de vida pela concepção negativa de dano moral.

Com o objetivo de desfazê-la e traçar um reconhecimento conceitual mais preciso à nova figura, este trabalho terá como marco teórico a contribuição de Carlos Fernández Sessarego. O professor da Universidade Católica do Peru propõe a classificação entre dano à pessoa e dano às coisas, imprimindo a natureza jurídica de dano à pessoa ao que denomina de "dano à liberdade fenomênica". Semelhante conformação teórica rende ao novo dano uma feição personalista, que se expressa na liberdade do ser humano projetar seu futuro em uma relação de coexistência. Atendo-se à perspectiva civil-constitucional, o trabalho depositará no livre desenvolvimento da personalidade o fundamento conceitual do dano ao projeto de vida, que se traduz no respeito e proteção à dignidade da pessoa humana. 
Utilizando-se do método dedutivo e do procedimento de pesquisa bibliográfico, o plano de trabalho divide-se em quatro partes. A primeira trata da noção de projeto de vida, à luz da contribuição do personalismo de Carlos Fernández Sessarego e da filosofia hiedeggariana. Outrossim, o livre desenvolvimento da personalidade é apresentado como um direito fundamental relacionado à abertura da cláusula de proteção dos direitos da personalidade. A segunda parte traça o contexto do dano ao projeto de vida no movimento dos "novos danos" na civilística brasileira. A terceira parte critica a identidade entre o dano moral e o dano extrapatrimonial por parte da doutrina e jurisprudência brasileiras, o que resulta na absorção do dano ao projeto de vida pelo dano moral. A quarta parte assinala a autonomia do dano ao projeto de vida com fundamento no livre desenvolvimento da personalidade e em sua qualificação como dano à pessoa.

\section{O PROJETO DE VIDA E O LIVRE DESENVOLVIMENTO DA PERSONALIDADE}

Para uma abordagem coerente do chamado direito ao livre desenvolvimento da personalidade é, antes de tudo, importante destacar o rompimento da noção estática e restritiva acerca do âmbito de proteção dos direitos da personalidade ${ }^{1}$. Este percurso histórico de abordagem e de compreensão dos direitos da personalidade foram imprescindíveis para ampliação da proteção da pessoa humana em sentido integral. Na perspectiva de Cristhian Magnus de Marco e Matheus Felipe de Castro, por exemplo, "o reconhecimento do direito geral de personalidade como princípio constitucional brasileiro tem como objetivo garantir o direito fundamental ao livre desenvolvimento da personalidade"

Essa mesma perspectiva é assumida por Elimar Szaniawski ao dispor que o "direito geral de personalidade ressurgiu e se afirmou no direito alemão (...) que, em seu art. 1. ${ }^{\text {o, }}$, declara ser intangível a dignidade do homem e em seu art. 2. ${ }^{\circ}$, reconhece o livre desdobramento da personalidade" ${ }^{13}$. A consideração apresentada corresponde a acertada postura doutrinária que assume a importância primeira do pleno reconhecimento jurídico de

\footnotetext{
${ }^{1}$ Neste sentido, importante e já paradigmático artigo de José Lamartine Correa de Oliveira e Francisco José Ferreira Muniz se destaca. OLIVEIRA, José Lamartine Corrêa. MUNIZ, Francisco José Ferreira. O Estado de direito e os direitos da personalidade. Tese apresentada à VII Conferência Nacional da Ordem dos Advogados do Brasil. passim.

2 MAGNUS DE MARCO, Cristhian; DE CASTRO, Matheus Felipe. As dimensões e perspectivas do direito fundamental ao livre desenvolvimento da personalidade. Prisma jurídico, v. 12, n. 1, jan.-jun., p. 13-49 (esta página é a 42). Universidade Nove de Julho. São Paulo. Disponível em: WWW.redallyc.org. Acesso em: 14 de abril de 2014.

${ }^{3}$ SZANIAWSKI, Elimar. Direitos da personalidade e sua tutela. São Paulo: RT, 1993. p.
} 
uma cláusula aberta dos direitos da personalidade. Esta, então, voltada à proteção do integral feixe de manifestações provenientes da própria natureza da pessoa humana. O retro citado jurista, vincula como necessários elementos para a concepção do direito geral de personalidade, tanto a dignidade do homem quanto o direito ao livre desenvolvimento de sua personalidade, demonstrando em consequência, a complexidade de abordagem pela amplitude semântica dos termos, e a central reputação da temática na busca da melhor tutela da pessoa humana.

A inclinação doutrinária no sentido de se considerar a existência de um direito geral de personalidade, e, por conseguinte, de reputar saudável um amplo suporte fático também para o direito ao livre desenvolvimento de personalidade (como direito fundamental ${ }^{4}$ ), com evidente aplicação de uma cláusula geral, também é robustecida pela posição de Pietro Perlingieri. Para o civilista italiano, qualquer opção pela tipicidade estrita dos direitos da personalidade implicariam necessária desconsideração da normatividade e aplicabilidade imediata do enunciado normativo constitucional de proteção à dignidade humana 5 .

Este posicionamento aberto e disposto à consideração de uma integral tutela da pessoa humana, ou seja, aquela voltada à proteção de sua integridade psicofísica ${ }^{6}$, encontra-se em paralelo com as construções doutrinárias que insistem na necessária remodelação da responsponsabilidade civil. $\mathrm{O}$ vetusto, central e amplo instituto jurídico não haveria que se mostrar infenso à toda atividade neoconstitucionalizante ${ }^{7}$ que invade, axiológica e normativamente, toda a atividade e ordenamento jurídicos.

Assim, na esteira da necessária remodelagem, surge a importante contribuição latinoamericana de Carlos Fernández Sessarego ${ }^{8}$, para uma plena consideração da pessoa humana no Direito. Na leitura abalizada de Luiz Edson Fachin ${ }^{9}$, anota-se que o professor peruano "aponta, ainda, a liberdade pessoal como função principal do direito, mediante a convivência

\footnotetext{
${ }^{4}$ Acerca do conteúdo dos direitos fundamentais e da amplitude do respectivo suporte fático ver, por todos: SILVA, Virgílio Afonso da. O conteúdo essencial dos direitos fundamentais e a eficácia das normas constitucionais. Revista de Direito do Estado. Ano. 1. N. 4. Out/dez 2006. p. 23-51. passim.

${ }^{5}$ Leitura que se faz do posicionamento do autor em: PERLINGIERI, Pietro. Perfis do direito civil. 3 ed. Rio de Janeiro: Renovar, 2007. p. 154 e 155.

${ }^{6}$ PERLINGIERI, Pietro. Perfis do direito civil. 3 ed. Rio de Janeiro: Renovar, 2007. p. 159 e 160.

7 Tomamos aqui, como exemplo, a postura de constitucionalista italiano, para o qual a constitucionalização do Direito "Se trata de un proceso al término Del cual el Derecho es ‘impregnado', 'saturado'o 'embebido'por la Constitución: un Derecho constitucionalizado se caracteriza por una Constitución invasiva, que condiciona la legislación, la jurisprudência, la doctrina y los comporamientos de los actores políticos." (COMANDUCCI, Paolo. Formas de (neo)constitucionalismo: un análisis metateórico. In: CARBONELL, Miguel. Neoconstitucionalismo(s) Madrid: Trotta, 2003, pp. 75-98. p. 81.)

8 Dentre outras contribuições do jusfilósofo peruano para a compreensão da pessoa humana encontra-se interessante contribuição em: SESSAREGO, Carlos Fernández. Derecho a la identidad personal. Buenos Aires: Astrea, 1992. passim.

${ }_{9}^{9}$ FACHIN, Luiz Edson. Estatuto jurídico do patrimônio mínimo. 2 ed. Rio de Janeiro: Renovar, 2006. p. 47.
} 
comunitária" de valores jurídicos tais como a solidariedade, coexistencialidade e a liberdade ontológica.

Desta perspectiva conjunta de valores que orbitam a centralidade da condição de liberdade do homem, emerge de singularidade especial "não só o pleno desenvolvimento da pessoa individual, mas, simultaneamente, que as demais pessoas com as quais o indivíduo está em relação também possam ter esse desenvolvimento de forma solidária"10.

Para Carlos Fernández Sessarego a existência humana implica necessária liberdade individual. Porém, há que se tomar esta primazia da liberdade, como direito fundamental da personalidade, em sentido que transcende o individualismo da modernidade ${ }^{11}$. É neste aspecto que se soma ao valor moderno da individualidade o valor da solidariedade exercida pela necessária coexistencialidade. É assim que, explicando a posição do professor peruano dispõe Luiz Edson Fachin que o "projeto existencial do homem só é possível se os demais homens livres estiverem dispostos a cooperar solidariamente em sua realização"12. $\mathrm{O}$ valor primeiro de toda a contrução jurídica se encontra assim no valor da existencialidade do ser humano como ser liberdade, como, enfim, um verdadeiro ser-com os outros ${ }^{13}$.

Para o integral entendimento da pessoa humana e das projeções da personalidade que do ser exsurgem, todas tuteláveis por meio do reconhecimento do direito ao livre desenvolvimento da personalidade, o valor da liberdade é compreendido a partir do projeto de futuro. O ser humano para Martin Heidegger se encontra imerso, como "pre-sença" que é, em uma relação de abertura com o mundo. Esta abertura para o mundo existencial "se dá na forma de compreensão, que, por seu turno, possui um caráter projetivo e alcança toda a constituição ontológica do próprio `ser-no-mundo`"14. Martin Heidegger justifica então que o ser-em (como ser inserido no mundo da existência) é, necessariamente, um "poder-ser-nomundo"15, ou seja, se faz, se constrói, e ainda, "é" o que pode vir a ser. Esclarece Luis Recaséns Siches em bela passagem de "Vida humana Sociedad y Derecho", que:

\footnotetext{
${ }^{10}$ FACHIN, Luiz Edson. Estatuto jurídico do patrimônio mínimo. 2 ed. Rio de Janeiro: Renovar, 2006. p. 47.

$11 \mathrm{O}$ individualismo da modernidade se define a partir de um individualis mo "essencialmente não-social, portador dos nossos valores supremos, e que se encontra em primeiro lugar em nossa ideologia moderna do homem e da sociedade." DUMONT, Louis. O individualismo: uma perspectiva antropológica da ideologia moderna.Rio de Janeiro: Rocco, 2000. p. 37.

12 Demontrando aqui, a importante nota de coexistencialidade, solidariedade e vivência gregária pacífica para o livre desenvolvimento da personalidade humana. FACHIN, Luiz Edson. Estatuto jurídico do patrimônio mínimo. 2 ed. Rio de Janeiro: Renovar, 2006. p. 48.

13 Tratando da perspectiva existencialista da condição humana, na visão de DUSSEL da filosofia de HEIDEGGER, ver: MARRAFON, Marco Aurélio. Hermenêutica e sistema constitucional: a decisão judicial entre o sentido da estrutura e a estrutura do sentido. Florianópolis:Habitus, 2008. p. 151.

${ }^{14}$ MARRAFON, Marco Aurélio. Hermenêutica e sistema constitucional: a decisão judicial entre o sentido da estrutura e a estrutura do sentido. Florianópolis: Habitus, 2008. p. 153.

${ }^{15}$ HEIDEGGER, Martin. Ser e tempo: parte I. 15 ed. Petrópolis: Vozes, 2005. p. 200.
} 


\begin{abstract}
La vida no es un ser ya hecho, ni tampoco un objeto con trayectoria predeterminada; la vida no tiene una realidad ya hecha como la piedra, ni tampoco una ruta prefijada como la órbita del astro o el desarrolho del ciclo vegetativo de la planta. Es todo lo contrario; es algo completamente diverso: es un hacerse a sí misma, porque la vida no nos es dada hecha; es tarea; tenemos que hacer nos la en cada instante. Y esto no sólo en los casos de conflictos graves, sino siempre, en todo momento. $^{16}$
\end{abstract}

A vida da pessoa humana, como aludido acima, não se encontra como algo feito, pronto, ou ainda, como algo com trajetória pré estipulada pelo rotor do destino. A vida humana é necessariamente um fazer de si algo diverso. Então, sendo única, autonomiza, por consequência, cada indivíduo humano como detentor de características ${ }^{17}$ que o diferenciam dos demais. Esta mesma vida humana, central à compreensão do fenômeno jurídico ocupa, inquestionavelmente a condição causal da cláusula geral de tutela da personalidade, afinal, é por meio dela que se possibilita o suporte da própria personalidade ${ }^{18}$. No direito civil português, demonstrando sua convergência (re)personalizadora, adotou claramente uma tutela genérica em seu artigo $70^{19}$. A doutrina civilista alemã, por força de inspiração dos $\operatorname{artigos} 1^{\circ}$ e $2^{\circ}$ da Constituição alemã, também considera e reconhece um direito genérico da personalidade ${ }^{20}$. Já no Brasil vale-se a doutrina civilista abalizada, posto que o legislador do Código Civil não concedeu à personalidade a amplitude necessária possibilitada pela técnica da cláusula geral, da aplicabilidade direta do artigo $1^{\circ}$, III da Constituição Federal, recaindo a questão por sobre a noção de dignidade da pessoa humana ${ }^{21}$.

Capelo de Sousa ${ }^{22}$ bem considera que o homem, como ser que congloba sentimentos, inteligência e vontade e os une por meio da materialidade corporal que the é inerente, implica a configuração e desenvolvimento de forças que conjugam uma "dinâmica criadora", um "complexo criativo" de cada indivíduo, todo voltado à sua autodeterminação. Assim, uma

\footnotetext{
${ }^{16}$ SICHES, Luis Recaséns. Vida humana, sociedad y derecho: fundamentación de la filosofia del derecho. México: Fondo de Cultura Económica, 1939.

${ }^{17}$ CAPELO DE SOUSA, Rabindranath V. A.. O direito geral de personalidade. Coimbra: Coimbra Editora, 2011. p. 203.

${ }^{18}$ CAPELO DE SOUSA, Rabindranath V. A.. O direito geral de personalidade. Coimbra: Coimbra Editora, 2011. p. 204.

${ }^{19}$ Dispõe o Código Civil Português em seu artigo 70: (Tutela geral da personalidade) - 1. A lei protege os indíviduos contra qualquer ofensa ilícita ou ameaça de ofensa à sua personalidade física ou moral. 2. Independentemente da responsabilidade civil a que haja lugar, a pessoa ameaçada ou ofendida pode requerer as providências adequadas às circunstâncias do caso, com o fim de evitar a consumação da ameaça ou atenuar os efeitos da ofensa já cometida.

20 WESTERMANN, Harry. Código civil alemão: parte geral. Trad. FURQUIM, Luiz Dória. Porto Alegre: Sérgio Antonio Fabris, 1991. p. 38.

${ }^{21}$ Assim, v.g., dispõe: SCHREIBER, Anderson. Direitos da personalidade. 2 ed. São Paulo: Atlas, 2013. p. 15.

22 CAPELO DE SOUSA, Rabindranath V. A.. O direito geral de personalidade. Coimbra: Coimbra Editora, 2011. p. 238.
} 
efetiva tutela proveniente do direito civil precisa estar comprometida com a proteção dessa esfera ampla da personalidade criativa do ser humano, "excluindo ataques que visem eliminála ou diminuí-la, que a inibam, que a arrisquem ou que dela se aproveitem indevidamente."23 Engloba-se, assim, na proteção projectiva do ser humano, desde os trabalhos mais simplórios e cotidianos, até as realizações científicas ou tecnológicas mais complexas.

Dentre tantos aspectos circunscritos ao âmbito de proteção do direito ao livre desenvolvimento da personalidade humana (como, v.g., aqueles pautados no direito à saúde física e mental, à informação, à educação, à cultura, à ciência, à habitação, ao consumo, ao trabalho, ao meio ambiente, à segurança física, à segurança social, ao desporto, etc., seja por meio de exigências estatais, ou por meio de proteção à sua esfera de liberdades negativas) nomeadamente surge como expressão inelutável de seu ser, o "poder de autodeterminação (...) na possibilidade de escolha de finalidades ou objectivos, (...) na automodelação do carácter, do temperamento, do intelecto e do corpo e na adaptação sócio-ambiental, numa dinâmica de autoconstituição ou de autodesenvolvimento de sua personalidade individual"24. O ser humano, assim, é uma unidade psicossomática sustentado em sua liberdade sendo portanto, esta liberdade de fazer a si, o seu próprio núcleo existencial ${ }^{25}$. A liberdade como o próprio "ser" do homem não se compraz apenas em si própria, mas também na projeção concreta dos atos. Afina, se "decide para actuar, para vivir"26.

O ser humano é um ser "projectante" e "projectivo"27, pois, como ser liberdade é um constante e permanente poder-ser-no-mundo ${ }^{28}$. O projeto de vida do ser humano, mostra-se assim, como o mais importante aspecto da manifestação de sua própria humanidade na lição de Carlos Fernández Sessarego. Para o professor da Universidade Católica do Peru, define-se este crucial rasgo da humanidade como:

23 CAPELO DE SOUSA, Rabindranath V. A.. O direito geral de personalidade. Coimbra: Coimbra Editora, 2011. p. 239.

24 CAPELO DE SOUSA, Rabindranath V. A.. O direito geral de personalidade. Coimbra: Coimbra Editora, 2011. p. 239.

25 SESSAREGO, Carlos Fernández. Que és ser `persona para El derecho? Derecho PUC, nº 53, Universidad católica, 2002. $\quad$ p. 33 Disponível em: <

http://dike.pucp.edu.pe/bibliotecadeautor_carlos_fernandez_cesareo/articulos/ba_fs_13.PDF> Acesso em: 14 abr. 2014.

26 SESSAREGO, Carlos Fernández. El "proyecto de vida", merece protección jurídica? Disponível em: http://www.personaedanno.it/danni-non-patrimoniali-disciplina/el-proyecto-de-vida-merece-proteccion-juridica- carlosfernande z-sessare go> Acesso em: 14 abr. 2014. p. 14.

27 Os neologismos utilizados aqui advém de tradução livre das expressões de SESSAREGO, "proyectante" e "proyectivo". SESSAREGO, Carlos Fernández. El "proyecto de vida", merece protección jurídica? Disponível em: http://www.personaedanno.it/danni-non-patrimoniali-disciplina/el-proyecto-de-vida-merece- proteccion-juridica-carlosfernande z-sessare go> Acesso em: 14 abr. 2014. p. 14.

28 HEIDEGGER, Martin. Ser e tempo: parte I. 3 ed. Petrópolis: Vozes, 1989. p. 200. 
Se designa como el singular y único "proyecto de vida" aquel que la persona elige, en la intimidad de su mundo interior y en un determiando momento de su vida, con el propósito de realizarlo, de contemplarlo hecho realidad en el curso de su existencia. Es el rumbo, la meta, el sentido y razón que cada ser humano otorga al don de su vida. Es lo que el hombre decide ser y hacer "en" su vida y "con su vida". Vive para cumplir con su propio destino, es decir, para dar cumplimiento al proyecto que ha elegido en tanto "ser liberdade". ${ }^{29}$

Anota em obra destinada especificamente ao tema do dano ao projeto de vida, Osvaldo Burgos que: "Proyectar, construir un sentido, es vivir dignamente..$^{30}$ O projeto de vida do homem é parte essencial do próprio modo de vida do ser, sendo as manifestações de sua pessoa advindas de seu projeto de vida lícito, projeções da própria personalidade, merecedora de tutela intensa. Isto, porque a derrocada do projeto vital, desmonta a própria natureza do ser humano, atingindo-lhe o núcleo da dignidade e da própria condição como ser existencial.

É por meio do projeto de vida que a pessoa humana se singulariza e se constitui no mundo, ou seja, é traço que permite ao ser encontrar uma razão para sua própria existência. Trata-se de postura existencial assumida pelo ser enquanto avaliador das possibilidades de um vir-a-ser ${ }^{31}$. Define-se também o "projeto" como rumo que se pretende dar à vida, o que indica existir uma trajetória escolhida para trilhar o curso da existência, metas e realizações que o homem ou a mulher esperam poder alcançar no seio das relações existenciais e imersos na angústia da temporalidade finita.

É nesta esteira que o homem elege determinados planos laborais, profissionais, familiares, etc., e intenta perseguir certos valores que lhe são caros. Apontando a filosofia de Jaspers, Carlos Fernández Sessarego expõe que o projeto de vida "és aquel que el hombre, consciente de su liberdad, quiere llegar a ser lo que puede y quiere ser ${ }^{\prime \prime 2}$.

Osvaldo Burgos, jurista argentino já citado, encontra na impossibilidade de desfrute deste vir-a-ser do homem que se projeta como ser liberdade, uma verdadeira despersonalização ${ }^{33}$. O projeto de vida, sendo a própria essência do homem como ser liberdade, é, contudo, construído por variados projetos singulares que se sucedem

\footnotetext{
29 SESSAREGO, Carlos Fernández. El "proyecto de vida", merece protección jurídica? Disponível em: http://www.personaedanno.it/danni-non-patrimoniali-disciplina/el-proyecto-de-vida-merece-proteccion-ju rid icacarlos-fernandez-sessareg 0> Acessoem: 14 abr. 2014. p. 14.

${ }^{30}$ BURGOS, Osvaldo R. Daños al proyecto de vida. Buenos Aires: Astrea, 2012. p. 137.

${ }^{31}$ VALLE, Augustin Basave F. del. Filosofia do homem: fundamentos de antroposofia metafísica. São Paulo: Convívio, 1975. p. 35.

32 SESSAREGO, Carlos Fernández. E "proyecto de vida", merece protección jurídica? Disponível em: http://www.personaedanno.it/danni-non-patrimoniali-disciplina/el-proyecto-de-vida-merece-proteccion-ju rid icacarlos-fernandez-sessareg 0> Acessoem: 14 abr. 2014. p. 15.

${ }^{33}$ BURGOS, Osvaldo R. Daños al proyecto de vida. Buenos Aires: Astrea, 2012. p. 137.
} 
cotidianamente, mas que, ao cabo, desembocam "en el gran río"134 que é constituído pela própria liberdade fenomênica ${ }^{35}$.

Importante considerar que a construção da noção de "projeto de vida" para Carlos Fernández Sessarego, não está descuidada das implicações provenientes das impossibilidades. Ou seja, considera o autor, a existência de projetos de vida que se configuram como ideais, ou, em outros termos, de impossível concretização, ao que nomeia de "proyectos que desbordan las posibilidades reales del ser humano como aquellos fantasiosos o los imposibles de realizar"36. Não obstante, observa o jurista, que "existe un mandato, que nace de la propia dignidad de la persona, que es el de hacer todo lo posible por aproximarse a la perfección". ${ }^{37}$

Desta problemática surge outra que se verifica na maior ou menor nitidez de determinado projeto de vida, e, para além, da possibilidade mesma de se destruí-lo, modificálo, ou mitigá-lo por meio de ato ilícito contratual ou não. Cogita-se do dano a este projeto, que não se encontra plenamente definida na doutrina, até mesmo pela relativa escassez de deslindes acerca da temática. Anota-se que o dano ao projeto de vida não ocupa lugar de destaque na aplicação jurisprudencial latino-americana, e, no Brasil, encontram-se raras menções expressas a seu respeito. Para isso, procura contribuir a presente digressão, ou seja, buscando seu reconhecimento no contexto dos novos danos no direito brasileiro.

\section{OS NOVOS DANOS E O DANO AO PROJETO DE VIDA}

A ideia de dano ocupa um lugar primordial na responsabilidade civil. Está no centro do instituto jurídico e termina por refletir os valores que a cultura jurídica elege como interesses dignos de serem tutelados em dado momento histórico. No contexto do Direito liberal compreendido por sobre a ótica individualista, a relação entre a pessoa e os bens

\footnotetext{
34 SESSAREGO, Carlos Fernández. E "proyecto de vida", merece protección jurídica? Disponível em: http://www.personaedanno.it/danni-non-patrimoniali-disciplina/el-proyecto-de-vida-merece-proteccion-ju rid icacarlos-fernandez-sessarego> Acessoem: 14 abr. 2014. p. 16.

35 Explica Osvaldo R. BURGOS, valendo-se dos ensinamentos de SESSAREGO, que existem duas importantes vertentes da liberdade: a primeira consiste na liberdade ontológica, referindo-se ao mundo interior do ser, inalcançável tanto à percepção quanto para as possibilidades da regulação jurídica. A liberdade fenomênica seria então, a expressão exterior da liberdade ontológica, possibilitando e exigindo regulação jurídica que a tutele. BURGOS, Osvaldo R. Daños al proyecto de vida. Buenos Aires: Astrea, 2012. p. 139.

36 SESSAREGO, Carlos Fernández. E "proyecto de vida", merece protección jurídica? Disponível em: http://www.personaedanno.it/danni-non-patrimoniali-disciplina/el-proyecto-de-vida-merece-proteccion-ju rid icacarlos-fernandez-sessareg $0>$ Acessoem: 14 abr. 2014. p. 16.

37 SESSAREGO, Carlos Fernández. El "proyecto de vida", merece protección jurídica? Disponível em: http://www.personaedanno.it/danni-non-patrimoniali-disciplina/el-proyecto-de-vida-merece-proteccion-ju rid icacarlos-fernandez-sessareg 0> Acessoem: 14 abr. 2014. p. 16.
} 
patrimoniais (economicamente apreciáveis) induziu a grande importância dos danos patrimoniais (danos emergentes e lucros cessantes). Porém, se a pessoa humana passa a recuperar seu lugar de primazia, destacando-se pela condição de sua dignidade inerente, passam os danos imateriais (extrapatrimoniais) a estampar o respeito pelos direitos personalíssimos ${ }^{38}$.

Já aludido superficialmente em linhas anteriores, vale apontar para um movimento que na responsabilidade civil permite observar a emergência de novos danos ressarcíveis. Tratase, em realidade, de uma ampliação da ressarcibilidade que promove, inclusive, uma nova proposta semântica que se traduz em uma passagem da responsabilidade civil para um Direito de Danos. ${ }^{39}$ Tal modificação estrutural denota uma importante revisão do regime anterior (calcado na culpa e no ato ilícito) e um giro conceitual em direção à pessoa vitimada e ao dano injusto ${ }^{40}$.

O movimento de transformação da responsabilidade civil, em prol do desenvolvimento de um Direito de Danos que esteja fundamentado no valor da pessoa humana, e, por conseguinte, assentado mais nas consequências danosas sofridas pela vítima que na responsabilização do culpado, impõe considerar mais do que a "socialização da responsabilidade". ${ }^{41}$ A desmitificação dos danos extrapatrimoniais se encontra nessa esteira revolucionária. Em relação aos defeitos e lacunas da técnica do Direito Privado, assevera Orlando Gomes que "de todos os vícios que a contaminam, nada mais grave, nas suas consequiências, do que a deliberada dissimulação das transformações que agitam a ordem jurídica atual na sua evolução irresistível"42.

Daí restar à civilística brasileira voltar-se para a questão da proliferação dos danos ressarcíveis na responsabilidade civil, mormente, os danos extrapatrimoniais. Parece ser possível deduzir que a redução dos danos extrapatrimoniais à categoria terminológica do "dano moral", historicamente construído por sobre a noção de pretium doloris, traduz um rasgo de dissimulação das necessárias transformações que o Direito necessita perpassar. Nossa doutrina já assimilava que essa postura conservadora de manutenção de um insistente

\footnotetext{
${ }^{38}$ IGLESIAS, Sergio. Responsabilidade civil por danos à personalidade. Barueri: Manole, 2002. p. 29

${ }^{39}$ PIANOVSKIRUZYK, Carlos Eduardo. Comentários ao Acórdão proferido no REsp 1.096.325/SP: O “caso das pílulas de farinha" como exemplo da construção jurisprudencial de um "direito de danos" e da violação da liberdade positiva como "dano à pessoa". Disponível em: $<$ http://fachinadvogados.com.br/artigos/Comenta\%CC\%81rios\%20ao\%20Acor dao.pdf> Acesso em: 21 dez. 2014.

${ }^{40}$ GOMES, Orlando. Tendências modernas da reparação de danos. In. Estudos em homenagem ao Professor Silvio Rodrigues. Rio de Janeiro: Forense, 1980. p. 283.

${ }^{41}$ GOMES, Orlando. A crise do Direito. São Paulo: Max Limonad, 1955. p. 248.

${ }^{42}$ GOMES, Orlando. A crise do Direito. São Paulo: Max Limonad, 1955. p. 248.
} 
"vocabulário jurídico"43 que encolhe as possibilidades de adequação do ambiente jurídico ao contexto social (impedindo-se qualquer inovação terminológica) também tinha por objetivo a imobilização do Direito em suas bases liberais.

Dispunha Orlando Gomes, ainda quanto à dissimulação do Direito, que: "Conservando as mesmas palavras para designar situações diferentes, evita-se que 'a massa dos homens adquira consciência imediata das transformações sociais'". Continua o mestre baiano explicando que a "invariabilidade terminológica encerraria o Direito numa cabine compensada, para manter artificialmente condições de vida que a pressão externa não permite mais". ${ }^{44}$ Daí, por exemplo, moldar-sena consciência popular a suposta existência de uma indústria do dano moral que não contribui para a efetiva identificação dos caros aspectos da personalidade, não patrimoniais, lesionados pelo dano. Os mais simplórios dissabores da vida

coletiva e os mais gravosos danos à liberdade e à vida terminam igualmente rotulados, tendo igualmente esmaecidas suas considerações estruturais.

A técnica do Direito, insiste o jurista, não poderia fugir à sua missão. $\mathrm{O}$ movimento da técnica jurídica no século XXI deve atentar para os danos que atingem a pessoa humana, valor supremo que unifica a ética, a moralidade e o Direito ${ }^{45}$. Esta majoração das hipóteses de ressarcibilidade, segundo Anderson Schreiber, advém de uma acolhida, por parte do Poder Judiciário, de requerimentos indenizatórios sem demonstração de culpa, ou ainda, de nexo causal nos estritos moldes da responsabilidade civil de viés patrimonialista. ${ }^{46}$

Importante considerar, contudo, que não somente da flexibilização dos filtros da responsabilidade civil tradicional surge a ampliação da ressarcibilidade. Esse fenômeno contempla todo um movimento, já considerado, de personalização do Direito, com aberta convergência dos esforços doutrinários e jurisprudenciais no sentido de minimizar o sofrimento das pessoas vitimadas em detrimento da, por vezes inócua, punição do agente causador do dano.

Também o pluralismo jurídico, expressão jurídica de uma sociedade efetivamente democrática, plural e solidária, indica, por sua vez, o reconhecimento de "novos" direitos que implicam, por natural consequência, em reconhecimento de "novos" danos ${ }^{47}$.

Vem, o aspecto do dano, ocupando um lugar de destaque na doutrina e na jurisprudência em concorrência com os requisitos da culpa e do nexo causal. Se por um lado o

\footnotetext{
${ }^{43}$ GOMES, Orlando. A crise do Direito. São Paulo: Max Limonad, 1955. p. 248.

${ }^{44}$ GOMES, Orlando. A crise do Direito. São Paulo: Max Limonad, 1955. p. 248.

${ }^{45}$ DWORKIN, Ronald. Justice for hedgehogs. Cambridge: Harvard University Press, 2011 p. 255.

${ }^{46}$ SCHREIBER, Anderson. Novos paradigmas da responsabilidade civil. 5 ed. São Paulo: Atlas, 2013. p. 83.

${ }^{47}$ WOLKMER, Antônio Carlos. Pluralismo, justiça e legitimidade dos novos direitos. Revista Sequência, Florianópolis, n. 54, p. 95-106, jul. 2007
} 
dano verificável na responsabilidade civil clássica era de fácil constatação, ao menos sob a ótica da patrimonialidade, atualmente marca-se uma tendência em elevá-lo ao plano primordial, com vistas ao melhor atendimento da pessoa vitimada. Inegavelmente que no plano dos danos extrapatrimoniais, categoria inexistente no direito civil clássico calcado por sobre a ótica liberal-patrimonialista, a complexidade da temática segue par a par com a própria complexidade de compreensão do ser humano em seu mundo vivencial, psicológico, etc. Os eventos danosos e as consequiências que os mesmos impingem às pessoas têm, nesse caminho, conquistado a atenção de grande parte dos juristas atentos à inflexão personalista do Direito.

Maria Celina Bodin de Moraes observa que um aumento do rol de hipóteses de dano moral jurisprudencialmente reconhecidas é uma consequência do desenvolvimento dos direitos da personalidade ${ }^{48}$. A insigne autora, contudo, observa um aumento de hipóteses de danos extrapatrimoniais ressarcíveis sob a noção ampliada de "dano moral". Diferentemente propõe parte da doutrina estrangeira, que, em detrimento de um exagerado conceito de dano moral, conquista o reconhecimento conceitual de outros novos danos que com aquele não se confundem. Ao consolidar-se o edifício jurídico por sobre o valor da pessoa humana, exsurge a necessidade de reconhecer novos danos como os danos coletivos, estéticos, à saúde, biológicos, existenciais, e o dano ao projeto de vida.

Há, contudo, que se atentar para a posição de Anderson Schreiber, para o qual, citando o posicionamento de Tomasini, entende que o problema marcado pelo paradigma atual, assentado na compreensão dos mais diversos aspectos da existencialidade humana, pode operar uma expansão desmedida ${ }^{49}$, ou mesmo infinita, "das fronteiras do dano ressarcível". ${ }^{50}$ A parábola de Busnelli ${ }^{51}$, entretanto, se serve de alerta por um lado, de outro não pode mitigar

\footnotetext{
${ }^{48}$ MORAES, Maria Celina Bodin. Danos à pessoa humana: uma leitura civil-constitucional dos danos morais. Rio de Janeiro: Renovar, 2003. p. 165.

${ }^{49}$ Expõe Maria Celina Bodin de MORAES que: "Na verdade, ampliando-se desmesuradamente o rol dos direitos da personalidade ou adotando-se a tese que vê na personalidade umvalor e reconhecendo, emconsequencia, tutela às suas manifestações, independentemente de serem ou não consideradas direitos subjetivos, todas as vezes que se tentar enumerar as novas espécies de danos, a empreitada não pode senão falhar: sempre haverá uma nova hipótese sendo criada." Há, nesse sentido, que se apontar para um alerta necessário. MORAES citando Procida Mirabelli di LAURO acentua que, como já verificado por alguns na Itália, a situação enfrentada é de uma "'comédia da responsabilidade civil"'.

MORAES, Maria Celina Bodin. Danos à pessoa humana: uma leitura civil-constitucional dos danos morais. Rio de Janeiro: Renovar, 2003. p. 166.

${ }^{50}$ SCHREIBER, Anderson. Novos paradigmas da responsabilidade civil. 5 ed. São Paulo: Atlas, 2013. p. 92.

51 "F. D. BUSNELLI (3) denominó [asi] la parábola de la responsabilidad civil. Dice BUSNELLI que después de tantos escritos y profecías sobre el triunfo, el eclipse, la crisis, el ocaso y la muerte de la responsabilidad civil, es pertinente diseñar una parábola, en el sentido evangélico de esta expresión. Un curso de agua, alimentado por una antigua fuente, atraviesa un territorio y condiciona su explotación económica, que, en su origen, era fundamentalmente agraria. Cuando se produce el paso de una economía agrícola de puro sostenimiento a un desarrollo industrial cada vez más amplio, el flujo de agua se revela insuficiente y los expertos se tienen que
} 
a evolução da técnica jurídica tão necessária no ponto. Orlando Gomes em postura progressista bem asseverava que a "precipitação da evolução jurídica é menos nociva do que a mumificação das idéias defuntas" ${ }^{152}$.

O trajeto que a partir de agora se demonstrará, partirá do escólio de Carlos Fernández Sessarego, cuja sugestão para o impasse dos "novos" danos, ganha solução ao se classificar corretamente os danos causados à pessoa humana, adequando o Direito de Danos à realidade apresentada pela pessoa humana em sua condição temporal e de necessária coexistencialidade. $^{53}$

As modificações e esforços classificatórios do Direito de Danos hodierno pouco atingem os danos patrimoniais ${ }^{54}$, já meticulosamente conformados aos propósitos do direito de faceta liberal por meio da "teoria da diferença" (consequência econômica advinda do dano). As alterações de sentido da responsabilidade civil atingem, por certo, o âmbito da extrapatrimonialidade, o que demonstra, por si só, que tal empreita trilha o caminho da valorização da pessoa em seu plano existencial. Assinala Luis Diez Picazo que a doutrina e a jurisprudência já ultrapassaram a questão pertinente a indenizabilidade do dano moral. Ocorre, porém, uma nova questão: "Se trata de puntualizar el concepto mismo de daño moral, que, junto al idea de sufrimiento, dolor físico o psíquico, ha ido sucesivamente experimentado ampliaciones entre las que, a veces, se coloca la perdida de los placeres de la vida o daño de disfrute y algunos otros critérios similares". 55

Há que se criar, ao tratar dos novos danos ressarcíveis, critérios objetivos de reconhecimento e aferição ${ }^{56}$. É o que se pretende em relação ao dano ao projeto de vida.

ingeniar, construyendo diques y canales y realizando todo tipo de obras, para utilizar mejor y distribuir la escasa agua disponible. Más de repente, el curso de agua se acrecienta por la confluencia de pequeños arroyos, se descubren nuevas fuentes y entonces es preciso volver a llamar a los ingenieros, pero ahora para llevar a cabo obras de contención que permitan evitar las peligrosas inundaciones." BUSNELLI, F. D. apud. PICAZO, Luis Diez. Derecho de daños. Madrid: Civitas Ediciones, 1999. p. 242.

${ }^{52}$ GOMES, Orlando. A crise do Direito. São Paulo: Max Limonad, 1955. p. 254.

${ }^{53}$ SESSAREGO, Carlos Fernández. Deslinde conceptual entre "daño a la persona", "daño al proyecto de vida" $\quad$ "daño moral". $\quad$ Disponível em: <http://dike.pucp.edu.pe/ bibliotecadeautor_carlos_fernandez_cesareo/articulos/ba_fs_6.PDF > Acesso em 30 dez. 2014.

${ }^{54}$ Há que se anotar que existe no direito brasileiro uma corrente que defende a própria ampliação do conceito de patrimônio. Abarcaria-se, no conceito de patrimônio, além das relações patrimoniais da pessoa, outros diversos valores. FARIAS, Cristiano Chaves; ROSENVALD, Nelson. Curso de direito civil: parte geral e LINDB. 11 ed. Salvador: Juspodiun, 2013. p. 511. Defende-se, nessa linha, uma nova (pós-moderna) concepção funcionalizada (e constitucionalizadaa) de patrimônio e um novo conceito para o dano patrimonial. "O dano patrimonial deve servisto como o gênero de lesão, do qual dano material e dano moral se constituem em espécies." POPP, Carlyle; PARODI, Ana Cecília. A concepção pós-moderna de dano: releitura a partir do conceito constitucionalizado de patrimônio. In: GUNTHER, Luiz Eduaro; CARNEIRO, Maria Francisca. (Coord.) Dano moral e direitos fundamentais: uma abordagem multidisciplinar. Curitiba: Juruá, 2013. p. 64.

${ }_{55}$ PICAZO, Luis Diez. Derecho de daños. Madrid: Civitas Ediciones, 1999. p. 239-240.

${ }^{56}$ SCHREIBER, Anderson. Novos paradigmas da responsabilidade civil. 5 ed. São Paulo: Atlas, 2013. p. 109. 
Para Osvaldo Burgos o dano ao projeto de vida seria aquele que incide negativamente sobre o exercício mesmo da autonomia ou da autodeterminação responsável de outrem $^{57}$. Este grave dano imporia ao vitimado uma despersonalização a operar a própria coisificação do ente, isto, pois, lhe restariam negadas as escolhas vitais que faziam parte do seu próprio ser-liberdade.

Carlos Fernández Sessarego aponta então três ocorrências que remontam à causação de dano ao projeto de vida: a) uma frutração total do projeto de vida, terminando-se por acarretar um vazio existencial à pessoa vitimada; b) um dano parcial ao projeto de vida, sem impossibilitálo por completo, e; c) um dano que causa um retardamento (diferimento dos planos e da possível concretização dos mesmos) à consecução do projeto vital pelo vitimado ${ }^{58}$. O jusfilósofo esclarece estas maneiras de causação de danos ao projeto de vida a partir de três exemplos que seguem, respectivamente, a variação exposada acima, qual seja: a plena frustração, a frustração parcial, e o retardo do projeto de vida. Assim, um pianista que tem uma de suas mãos decepada, e um advogado que sofre o mesmo dano são exemplos de frustração plena e parcial dos projetos de vida. Ademais, uma prisão injusta que dure significativo tempo, pode apenas postergar a execução e realização dos planos do vitimado.

Compreende-se que tal dano ao projeto vital não apenas afeta o vitimado em termos patrimoniais, mas a difusão do dano compreende inclusive uma negação do sentido de pertencimento à comunidade outrora sensivelmente importante para a concretização de sua dignidade. Promove, um grave dano ao projeto de vida, a própria exclusão social do vitimado que perde importantes meios de desenvolvimento da personalidade ${ }^{59}$.

Evidente que a proposta doutrinária para reconhecimento de um autônomo dano ao projeto de vida implicará, como já vem ocorrendo, contestações e rechaçamentos. Veja-se, por exemplo, a posição de Jorge Mário Galdós, para o qual:

En una primera impresión el caráter dual del daño condujo a su encasillamiento en lo patrimonial, a través de la incapacidade o de la pérdida de chances, especialmente en el terreno laboral o productivo; y en el daño moral cuando se atienden a las afectaciones de intereses extrapatrimoniales ${ }^{60}$.

\footnotetext{
${ }_{58}^{57}$ BURGOS, Osvaldo R. Daños al proyecto de vida. Buenos Aires: Astrea, 2012. p. 137-138.

58 SESSAREGO, Carlos Fernández. E "proyecto de vida", merece protección jurídica? Disponível em: http://www.personaedanno.it/danni-non-patrimoniali-disciplina/el-proyecto-de-vida-merece-proteccion-ju rid icacarlos-fernandez-sessareg 0> Acessoem: 14 abr. 2014. p. 17.

${ }_{60}^{59}$ BURGOS, Osvaldo R. Daños al proyecto de vida. Buenos Aires: Astrea, 2012. p.138.

60 GALDÓS, Jorge Mario. Hay daño al proyecto de vida? Disponível em: <http://www.cmfbsas.org.ar/archivos/13_RP6-09-Hay\%20Dano\%20Proy\%20Vida_.pdf> Acesso em: 14 abr. 2014.
} 
Põe-se aqui uma indefinição acerca da categorização do dano ao projeto de vida, partindo-se de uma suposta necessidade de categorização deste grave dano à pessoa partindose da clássica distinção entre dano moral e dano patrimonial. A construção teórica da autonomia do dano ao projeto de vida, porém, vai além da mera qualificação entre dano moral e patrimonial que parece consubstanciar, atualmente, uma "summa divisio" de inflexibilidade insuperável.

\section{A ABSORÇÃo dO DANO AO PROJETO DE VIDA PELO DANO MORAL}

No contexto de reinterpretação do Direito sob a ótica da promoção da dignidade humana, se assenta a preocupação acerca de uma nova compreensão dos danos à pessoa. Contudo, insiste a doutrina e a jurisprudência tradicionais em apontar dois grandes grupos de danos que compreenderiam todas aquelas situações injustas que seriam tuteláveis pelo Direito e passíveis de responsabilização civil: os danos patrimoniais e os danos morais (imateriais ou não patrimoniais). ${ }^{61}$

Veja-se que, como alerta Sérgio Cavalieri Filho, hoje a doutrina se debate no sentido de buscar um conceito para o difundido "dano moral"62. Ademais o mesmo estudioso da responsabilidade civil descreve que há conceitos negativos e positivos acerca do dano moral: os negativos terminam por admitir o dano moral como aquele que não se fundamenta na existência de danos patrimoniais, e, os positivos, se consagrariam pela existência de "dor, vexame, sofrimento, desconforto, humilhação - dor da alma." ${ }^{93}$ Porém, na esteira de adequar a conceituação do dano moral às disposições constitucionais de tutela da dignidade da pessoa humana, adverte acerca de tais conceituações que:

\footnotetext{
Tenho para mim que todos os conceitos tradicionais de dano moral terão que ser revistos pela ótica da Constituição de 1988. Assim é porque a atual Carta, na trilha das demais Constituições elaboradas após a eclosão da chamada questão social, colocou o Homem no vértice do ordenamento jurídico da Nação, fez dele a primeira e decisiva realidade, transformando os seus direitos no fio condutor de todos os ramos jurídicos. Com efeito, a par dos direitos patrimoniais, que se traduzem em uma expressão econômica, o homem é ainda titular de relações jurídicas que, embora despidas de expressão pecuniária intrínseca, representam para o seu titular um valor maior, por serem atinentes à própria natureza humana. São os direitos da personalidade, que ocupam posição supraestatal, dos quais são titulares todos os seres humanos a partir do nascimento com vida (Código Civil, arts. 12 e 22). São direitos inatos, reconhecidos pela ordem jurídica e não outorgados, atributos inerentes à personalidade, tais como o direito à vida, à liberdade, à saúde, à honra,

ao nome, à imagem, à intimidade, à privacidade, enfim, à própria dignidade da pessoa humana. 64
}

\footnotetext{
${ }^{61}$ DIAS, José de Aguiar. Da responsabilidade civil. 11. ed. Rio de Janeiro: Renovar, 2006. p. 973.

${ }^{62}$ CAVALIERI FILHO, Sérgio. Programa de responsabilidade civil. 10. ed. São Paulo: Atlas, 2012. p. 88.

${ }^{63}$ CAVALIERI FILHO, Sérgio. Programa de responsabilidade civil. 10. ed. São Paulo: Atlas, 2012. p. 88.
} 
Entende Sérgio Cavalieri Filho que o "dano moral não está necessariamente vinculado a alguma reação psíquica da vítima. Pode haver ofensa à dignidade da pessoa humana sem dor, vexame, sofrimento, assim como pode haver dor, vexame e sofrimento sem violação da dignidade". Vincula o jurista o dano moral ao dano de personalidade, continuando a expor que: "Os bens que integram a personalidade constituem valores distintos dos bens patrimoniais, cuja agressão resulta no que se convencionou chamar de dano moral.” Assim, verifica-se que o dano moral adquiriu status jurídico autônomo em relação aos danos patrimoniais.

Verifica-se que o jurista acima citado engloba no chamado dano moral, todos os danos imateriais possíveis de sofrer a personalidade humana. O dano moral geralmente é estruturado na doutrina civilista a partir de elementos outros que não o do ente lesado, indicando que a classificação não pontua como centro de sua compreensão a pessoa humana. Veja-se neste exato sentido a já clássica postura de José Aguiar Dias, para o qual: "Quando ao dano não correspondem as características do dano patrimonial, dizemos que estamos em presença do dano moral". E, continua, demonstrando que: "A distinção, ao contrário do que parece, não decorre da natureza do direito, bem ou interesse lesado, mas do efeito da lesão, do caráter da sua repercussão sobre o lesado". ${ }^{65}$

Trata-se de uma prática observável na doutrina e jurisprudência brasileiras, igualmente retratada no dano ao projeto de vida, cogitando-se de sua absorção pelo dano moral. Essa visão restritiva deixa de incluir danos à pessoa na lógica do ressarcimento, impedindo íntegra reparabilidade ou compensação. Clóvis do Couto e Silva já observava a questão, dispondo que nossa jurisprudência, por exemplo, não inclui

... a figura que os autores franceses denominam de 'préjudice d'agrément' (...) [que] em sua concepção mais estrita, é o dano pela perda do que normalmente se pratica como lazer, como a impossibilidade de realizar atividades esportivas e culturais. Não é fácil separar, em alguns casos, essa indenização do pretium doloris e até mesmo do dano estético, podendo até mesmo o préjudice d'agrément abranger a perda do gosto, do olfato, quando considerado no seu sentido mais amplo. ${ }^{66}$

\footnotetext{
${ }^{64}$ CAVALIERI FILHO, Sérgio. Programa de responsabilidade civil. 10. ed. São Paulo: Atlas, 2012. p. 88.

65 DIAS, José de Aguiar. Da responsabilidade civil. 11. ed. Rio de Janeiro: Renovar, 2006. p. 992.

${ }^{66}$ SILVA, Clóvis Virgílo do Couto. O conceito de dano no direito brasileiro e comparado. In: FRADERA, Vera Maria Jacob de. (org.). O direito privado brasileiro na visão de Clóvis do Couto e Silva. Porto Alegre: Livraria do Advogado, 1997. p. 233.
} 
Carlos Fernández Sessarego inova, porém, o sistema de classificação dos danos, afastando-se daquela sistemática mais difundida, qual seja, a distinção entre danos materiais e imateriais (conforme já apontado acima), e pontua com nitidez uma classificação que releva a característica ontológica do sujeito/objeto que sofre efetivamente o dano ${ }^{67}$. O dano subjetivo se revela no daño a la persona e o dano objetivo no "daño a las cosas" $" 68$. O primeiro é aquele pertinente ao dano à pessoa humana passível de ocorrência no interregno que vai de seu nascimento à sua morte, enquanto o segundo é o dano que recai sobre as coisas, objetos conhecidos ou utilizados pelo homem e pela mulher. Esta distinção encontra sentido, quando se observa que: "No es lo mismo causar un daño a un ser humano, ya sea en su libertad, en su vida, en su honor o en su intimidad, que causar un daño a un automóvil o a una cosa cualquiera. ${ }^{, 69}$ A partir desta distinta classificação Carlos Fernández Sessarego identifica o dano moral como "una modalidade del daño a la persona ${ }^{70}$ y, por consiguiente, (...) una espécie de un concepto comprensivo, es decir, de una noción genérica que lo engloba y subsume". Nesse sentido, sua doutrina entende que é importante marcar a distinção entre a expressão dano moral e a expressão mais atual do dano à pessoa, com fito a delinear e redimensionar cada um destes conceitos para que se possa melhor compreender o desenvolvimento da doutrina e da jurisprudência contemporâneas. Evitar-se-ia, assim, confusões e imprecisões desnecessárias ou superposições de conceitos que tendem a gerar confusão.

Do gênero dano subjetivo, ou dano à pessoa humana distingui-se outros danos passíveis de acometerem a pessoa vitimada pelo ato injusto. Destarte, pode o dano à pessoa humana "lesionar algún aspecto de la unidad psicosomática (soma o psique) o puede afectar a la libertad fenómenica, o ejercicio mismo de la libertad, es decir y en otros términos, al "proyecto de vida".71 Carlos Fernández Sessarego procura demonstrar uma classificação

\footnotetext{
${ }^{67}$ SESSAREGO, Carlos Fernandez. Apuntes acerca del daño a la persona. El articulo ha sido publicado en el libro "La persona humana", dirigido por Guillermo A. Borda, Editora "La Ley", Buenos Aires, 2001. Disponível em <http://dike.pucp.edu.pe/bibliotecadeautor_carlos_fernandez_cesareo/articulos/ba_fs_4.PDF>. p. $\quad 16 . \quad$ Acesso em $01 /$ set/2013.

${ }^{68}$ SESSAREGO, Carlos Fernandez. Apuntes acerca del daño a la persona. El articulo ha sido publicado en el libro "La persona humana", dirigido por Guillermo A. Borda, Editora "La Ley", Buenos Aires, 2001. Disponível em <http://dike.pucp.edu.pe/bibliotecadeautor_ _carlos_fernandez_cesareo/articulos/ba_fs_4.PDF>. p. $16 . \quad$ Acesso em $01 /$ set/2013.

${ }^{69}$ SESSAREGO, Carlos Fernandez. Apuntes acerca del daño a la persona. El articulo ha sido publicado en el libro "La persona humana", dirigido por Guillermo A. Borda, Editora "La Ley", Buenos Aires, 2001. Disponível em 〈http://dike.pucp.edu.pe/bibliotecadeautor_carlos_fernandez_cesareo/articulos/ba_fs_4.PDF〉. p. $\quad 17 . \quad$ Acesso em $01 /$ set/2013.

${ }^{70}$ Traduziremos o termo "daño a la persona" como "dano à pessoa humana".

71 SESSAREGO, Carlos Fernandes. Deslinde conceptual entre "daño a la persona", daño al proyecto de vida" $\quad$ “daño moral". Disponível em: <http://dike.pucp.edu.pe/bibliotecadeautor _carlos_fernandez_cesareo/articulos/ba_fs_6.PDF> Acesso em: 02/set/2013.
} 
lógica dos danos pautando-se na dignidade da pessoa humana como centro irradiador das conceituações $^{72}$. Parte, o jurista peruano, dos enfoques trabalhados na filosofia existencialista que redescobre o ser humano como ser livre e voltado à, dentro de suas circunstâncias e múltiplos condicionamentos, projetar sua vida, no sentido de ser, escolher e valorar suas opções de vida ${ }^{73}$.

No Brasil, como informa Maria Celina Bodin de Moraes, a Constituição de 1988 faz incidir uma nova ordem jurídica pautada na "primazia das situações existenciais sobre as situações de cunho patrimonial" ${ }^{\text {,74, }}$, numa evidente opção que dá lugar à pessoa humanizada frente àquela tão somente abstrata, de aspecto liberal e proprietário que até então ainda insistia em tomar primeiro lugar na tábua dos valores juridicamente tutelados e na realidade das relações sociais. Justamente deste raciocínio assentado no respeito ao princípio constitucional de proteção à dignidade da pessoa humana é que se pretende compreender melhor os danos à que a pessoa humana está sujeita no mundo da coexistência ${ }^{75}$.

A postura de Carlos Fernández Sessarego parece sugerir que o centro da classificação se modifique para o ente lesado, e, neste sentido, aponta para os vários tipos de danos que podem atingir a pessoa humana em si, e não sobre seu patrimônio (material ou não). O esforço conceitual se dá na esteira da compreensão da responsabilidade civil a partir de uma postura mais personalista e menos patrimonialista/proprietária.

Sendo assim a contemporânea noção da natureza do dano moral para Carlos Fernández Sessarego, não seria outra que "una perturbación psicológica de carácter no patológico, generalmente transitória." Essa específica conotação do dano moral, e seu consequente uso indiscriminado para todas os fenômenos de causação de danos não patrimoniais, termina por impedir uma plena compreensão da íntegra tutela da pessoa humana. Já se poderia apontar em Clóvis Veríssimo do Couto e Silva, há mais de duas décadas, a noção de dano à pessoa como gênero no qual se inseria o especial dano moral. Veja-se que sua postura quanto ao dano à pessoa se dava numa acepção larga: 'Um dos aspectos mais importantes da responsabilidade civil é constituído pelos danos à pessoa. À

\footnotetext{
${ }^{72}$ Note-se que o dano à unidade psicossomática compreende a "alma e o espírito" humano, ou seja, o ser humano em sua totalidade psíquica e física.

${ }_{74}^{73}$ SESSAREGO, Carlos Fernández. Derecho a la identidad personal. Buenos Aires: Astrea, 1992. p. 2-3.

${ }^{74}$ MORAES, Maria Celina Bodin de. O conceito de dignidade humana: substrato axiológico e conteúdo normativo. In: SARLET, Ivo Wolfgang (Org.). Constituição, Direitos Fundamentais e Direito Privado. Porto Alegre: Livraria do Advogado, 2003. cap. 4, p. 137.

${ }^{75}$ A efetiva promoção da pessoa humana relacional tem de ser compreendida na medida de que a mesma é "serno-mundo-com-os-outros". FROTA, Hindemberg Alves. O Fundamento Filosófico do Dano Existencial. Disponível em: <http://tematicasjuridicas.wordpress.com/2011/11/02/dano-existencial-fundamento-filosofico> Acesso em: 07/10/ 2012.
} 
medida que o conceito de pessoa se transforma, novos danos são a ele acrescidos, em decorrência mesmo de uma visão mais integral desse conceito. ${ }^{, 76}$ É neste sentido que se pode compreender o dano à pessoa humana, qual seja, no aspecto de gênero no qual "novos" danos podem ser compreendidos na medida histórica de reconhecimento de "novos" direitos da personalidade.

\title{
4. O DANO AO PROJETO DE VIDA COMO DANO À PESSOA
}

O reconhecimento da tutela ao projeto de vida é importante passo na proteção do direito fundamental de liberdade do ser humano, que dirige seu próprio destino e determina suas metas, planos e aspirações existenciais ${ }^{77}$. Ao se caracterizar o atentado ao projeto de vida, tais danos impedem ou dificultam o livre desenvolvimento da personalidade, seja na carreira projetada, nos projetos que caracterizam a pessoa em sua singularidade, suas escolhas de vida, realizando sua dimensão existencial ${ }^{78}$. Em favor desta concepção de projeto de vida, afirma Youssef Cahali:

\begin{abstract}
....trata-se de um dano profundo, que compromete, de algum modo, o ser mesmo do homem; é um dano que afeta a liberdade da pessoa e que daí, substitui ou frustra o projeto de vida, que, livremente, formula cada pessoa e através do qual se realiza como ser humano: trata-se de um dano que trunca o projeto de vida, que impede, como resultado, que a pessoa desenvolva livremente a sua personalidade. (...) trata- se de um dano que, a partir ou tendo como origem um dano à saúde, impede a pessoa de cumprir, plena ou parcialmente, seu projeto de vida ${ }^{79}$.
\end{abstract}

Com efeito, amparando-se em um personalismo jurídico é possível caracterizar o dano ao projeto de vida como uma violação do direito ao livre desenvolvimento da personalidade. No direito brasileiro, essa afirmação sinaliza para a incidência dos direitos fundamentais nas relações privadas, uma vez que na Constituição da República não há previsão expressa do direito ao livre desenvolvimento da personalidade. Trata-se de um princípio implícito, que decorre da afirmação do princípio da dignidade da pessoa humana

\footnotetext{
76 SILVA, Clóvis Virgílo do Couto. O conceito de dano no direito brasileiro e comparado. In: FRADERA, Vera Maria Jacob de. (org.). O direito privado brasileiro na visão de Clóvis do Couto e Silva. Porto Alegre: Livraria do Advogado, 1997. p. 227.

77 SESSAREGO, Carlos Fernández. El daño al proyecto de vida en una reciente sentencia de la Corte Interamericana de Derechos Humanos. Revista de Responsabilidad Civil y Seguros, ed. "La Ley", Buenos Aires, año 1999, p. 1324.

78 MARTINS-COSTA, Judith. Comentários ao novo Código Civil. Do inadimplemento das obrigações (Coord. Sálvio de Figueiredo Teixeira) v. V, tomo II (arts. 389 a 420). Rio de Janeiro: Forense, 2004, p. 343.

79 Apud MARTINS-COSTA, Comentários..., p. 343.
} 
(art. 1 ${ }^{\circ}$, III, da Constituição da República) e dos direitos fundamentais de liberdade e igualdade (art. $5^{\circ}$, caput, e art. 170, da Constituição da República), arrematando Marcos de Campos Ludwig:

\begin{abstract}
Entende-se, em suma, que é a partir da composição de todas essas normas constitucionais as seguradoras de direitos e garantias fundamentais, comfulcro comum na dignidade da pessoa humana, que se torna possível compreender o direito ao livre desenvolvimento da personalidade como princípio geral do Direito brasileiro embora não haja, em nossos textos legais, referência expressa ao mesmo ${ }^{80}$.
\end{abstract}

A partir dessas premissas torna-se possível imprimir autonomia ao dano ao projeto de vida em face do dano moral. Eis que o dano ao projeto de vida parte do pressuposto que o ser humano é limitado no plano existencial e temporal ${ }^{81}$, o que se traduz em dizer que ele só pode realizar seus projetos no tempo de vida. Portanto, o dano ao projeto de vida caracteriza- se como aquele que acompanha o tempo de vida da pessoa. Por outras palavras, fere "la manera en que el sujeto ha decidido vivir, que trunca el destino de la persona, que le hace perder el sentido mismo de su existencia ",

O dano ao projeto de vida traduz a proteção do sentido existencial da pessoa, como ser social e temporal, que integra parcela imprescindível de seu desenvolvimento. Apartandose do dano moral, o dano ao projeto de vida consiste na situação injustamente imposta ao ser humano, que o impede de ter a

\begin{abstract}
possibilidade fática de praticar, baseado em seu livre-arbítrio, conjunto de atos imprescindíveis à execução de planejamento razoável e adaptável de metas e aspirações pessoais (plausíveis e exequíveis) que dão sentido à sua existência e representam aspecto central de sua busca pela autorrealização ${ }^{83}$.
\end{abstract}

Remontando à estrutura classificatória de Carlos Fernández Sessarego, surge a figura do dano ao projeto de vida, ou, como termo menos difundido, o "dano à liberdade fenomênica da pessoa humana". Compreende-se aqui, a novidade e o esforço teórico do jurista peruano

\footnotetext{
${ }^{80}$ LUDWIG, op. cit., p. 292.

81 "El ser humano es tiempo. Constituye un proceso temporal, abierto, donde el pasado condiciona el presente y, desde éste, se proyecta el futuro. El futuro está, por ende, dado en el presente en forma de proyecto. Si el ser humano es temporal es, también y por consiguiente, un ser histórico. La libertad en el tiempo, la vida temporal de la libertad, hacen posible que cada ser humano se proyecte, se realice, despliegue su personalidad, tenga una biografía y una identidad." (SESSAREGO. Carlos Fernández. El danõ al proyecto de vida. Disponível em: < http://dike.pucp.edu.pe/bibliotecadeautor carlos fernandez cesareo/articulos/ba fs 7.PDF> Acesso em $02 /$ set/2013).

${ }^{82}$ SESSAREGO, Carlos Fernández. Apuntes...,p. 42.

${ }^{83}$ FROTA, op. cit., p. 129-163.
} 
em buscar a plena compreensão das manifestações da personalidade humana por meio da exposição do dano ao projeto de vida. O que se observa é a necessária atenção ao "novo dano", buscando acatar seus pontos positivos e levar à discussão seus pontos ainda obtusos, no sentido de promover a responsabilidade civil ao passo acelerado da constitucionalização dos demais institutos jurídicos. A necessidade é premente, mormente quando se verificam incontáveis afrontas à noção descuidadamente ampliada do dano moral como única expressão possível de causação do dano injusto à pessoa humana.

A multiplicidade de expressões da vida humana provenientes do ser em liberdade, que é o homem, implica considerar com maiores cautelas as possibilidades aventadas pela novel compreensão do dano à pessoa humana, incluindo-se aí, o dano ao projeto de vida. Reconhecer na cláusula da tutela geral de personalidade a imposição constitucional ao respeito ao livre desenvolvimento de personalidade, é reconhecer também a impossibilidade de tratativas meramente patrimoniais da indenização. Frise-se que a "summa divisio" da responsabilidade civil hodierna, ainda repousa sob a lógica da patrimonialidade ou não- patrimonialidade do dano. Esquecida está a posição central da pessoa vitimada, obscurecida pela lógica proprietária que insiste em não abandonar o direito civil do terceiro milênio. Há que se alçar novos vôos nessa empreita de difíceis contornos. $\mathrm{O}$ dano à pessoa significa um dano a um bem ou interesse da pessoa como projeto existencial, e isto, "é muito mais complexo que o sofrimento ou a dor ${ }^{\prime \prime 4}$.

Necessária a modificação da difusão doutrinária, até então modesta no Brasil, da terminologia dos "danos à pessoa" como categoria maior e primordial para o regime jurídico dos danos compensáveis. Judith Martins-Costa bem esclarece tal situação da doutrina e da jurisprudência, dispondo que: "Raros são os textos, doutrinários ou jurisprudenciais, que utilizam a expressão 'danos à pessoa' para indicar a vasta categoria dos atentados à personalidade, como o faz Clóvis do Couto e Silva (...) (185 $^{18}$ A nota da jurista parece pouco ter se modificado desde então. Prossegue anotando que também são raras as decisões judiciais que distinguem os danos estritamente psíquicos dos danos morais. A autora, contudo, acredita ser a categoria dos danos extrapatrimoniais mais ampla e englobante da categoria dos danos à pessoa (ou à personalidade), estando nesta os danos morais em sentido próprio (honra, reputação), danos à imagem, projeção social da personalidade, danos à saúde, danos à

\footnotetext{
${ }^{84}$ Em tradução livre: SESSAREGO, Carlos Fernández. E daño al proyecto de vida. Disponível em: <http://dike.pucp.edu.pe/bibliotecadeautor_carlos_fernandez_cesareo/articulos/ba_fs_7.PDF > Acesso em: 14 abr. 2014.

${ }^{85}$ MARTINS-COSTA, Judith. Os danos à pessoa e a natureza de sua reparação. In: direito privado. São Paulo: Revista dos Tribunais, 2002. 408-446. p. 423. A reconstrução do
} 
integridade psicofísica "inclusos os 'danos ao projeto de vida' e ao livre desenvolvimento da personalidade, os danos à vida de relação, inclusive o 'prejuízo de afeição' e o danos estéticos." 86 Incluir-se-ia, para além, todos os outros danos que não atingindo o patrimônio ou a personalidade, resultariam em lesão ao meio ambiente.

A posição da insigne jurista não se detém na formulação primária de Carlos Fernández Sessarego, porém, com destaque, demonstra a imprescindibilidade de uma novel compreensão da categoria dos danos extrapatrimoniais, ressaltando, de forma inovadora na doutrina civil brasileira, a necessidade de apreensão do conceito do "dano ao projeto de vida". Assevera, finalmente, que a absolutização da terminologia "dano moral" é "conotação redutora [e] tem impedido (...) a adequada apreensão, pela jurisprudência de novas fattispecies que poderiam ser mais livremente desenvolvidas (...)." $\mathrm{Na}$ Argentina, por exemplo, se observa, hodiernamente, grande desapego ao conceito de dano moral em favor da adoção das expressões "dano à pessoa" ou "danos extrapatrimoniais" 87.

A visão do mesmo jurista é dada em outro momento (em referência à opção feita pelo Código Civil peruano em adotar a noção de "dano à pessoa"88) e citada por Carlos Fernández Sessarego. Nesta, há evidente opção pela noção de dano à pessoa a suplantar vetustos posicionamentos doutrinários em prol da inclinação das novas construções jurídicas em direção à realidade, como atenta o professor da Universidade Católica do Peru: "la reparación del dolor es ahora un capítulo, pero no toda la materia. Com dolor o sin él, se debe respetar la intimidad, la vida de relación, los proyectos, la salud, entendida de una manera plena e integral". ${ }^{89}$ Por conseguinte, o dano ao projeto de vida é compreendido como dano à pessoa ${ }^{90}$.

${ }^{86}$ MARTINS-COSTA, Judith. Os danos à pessoa e a natureza de sua reparação. In: _. A reconstrução do direito privado. São Paulo: Revista dos Tribunais, 2002. 408-446. p. 426-427

87 Da evolução do direito argentino acerca da concepção restrita "(...) resulta-se difícil falar de 'dano moral' (...). Começa a falarse de 'dano a pessoa'". LORENZETTI, Ricardo Luis. Fundamentos do direito privado. São

Paulo: Revista dos Tribunais, 1998. p. 458.

${ }^{88} \mathrm{O}$ artigo 1985 do Código Civil peruano prescreve que é obrigatória a reparação das consequências geradas do dano à pessoa. Trata-se de uma ampla noção que engloba danos ao corpo e danos ao estado psíquico.

${ }^{89}$ ITURRASPE, Jorge Mosset. apud. SESSAREGO, Carlos Fernandes. Deslinde conceptual entre “daño a la persona", daño al proyecto de vida" $y$ "daño moral". Disponível em: <http://dike.pucp.edu.pe/bibliotecadeautor_carlos_fernandez_cesareo/articulos/ba_fs_6.PDF> Acesso em: $82 / \mathrm{set} / 2013$. p. 65.

90 "Los daños extrapatrimoniales - en el sentido no por los vienes materiales - comprenden los daños a la persona humana (...) y entre ellos, los denominados 'daños a los derechos de la personalidad por derechos humanos', que abarcan los perjuicios a esos derechos en sus diversas 'generaciones' y que van desde 'el derecho

a la vida' - y a la salud - a los derechos a la integridad psicofísica, a los derechos a la liberdad, a la dignidad, al buen nombre y honor, al nombre, a la identidad estática y dinamica, a la no discriminación, a la igualdad, a trabajar y desarrollarse; pasando por el respecto a los 'datos personales', al medio ambiente sano, a la persona humana como consumidora de bienes y servicios; a la intimidad y seguridad personal, al respecto a la vida de relación, al pleno disfrute de la vida y a los proyectos de vida." (ITURRASPE, Jorge Mosset. El daño a la persona (como culminación de una larga evolución), Revista de Derecho de Daños, n. 3, 7-18. p. 14.) 


\section{CONSIDERAÇÕES FINAIS}

A ruptura com uma noção estática e restritiva dos direitos da personalidade tornou-se possível com o reconhecimento do direito fundamental ao livre desenvolvimento da personalidade, possibilitando uma tutela integral da pessoa humana por meio de uma cláusula geral. Esta compreensão foi elaborada por uma interpretação do Código Civil alemão à luz da Constituição, alcançando o art. 70 do Código Civil português. Contudo, ela não se fez presente no Código Civil brasileiro de 2002. Entre nós, a abertura de tutela dos direitos da personalidade é possibilitada por uma aplicação direta do artigo $1^{\circ}$, III, da Constituição da República, recaindo a questão na noção de dignidade da pessoa humana.

No direito latino-americano, a contribuição de Carlos Fernández Sessarego permite compreender que a existência humana implica em primazia da liberdade como direito fundamental da personalidade. Contudo, ela transcende o individualismo da modernidade, conferindo à liberdade um valor de solidariedade. Com apoio na filosofia heideggariana, é possível afirmar que a existência do homem se dá em relação aberta com o mundo, pois o homem se constrói e projeta seu futuro. Deste modo, o direito ao livre desenvolvimento da personalidade permite compreender o homem como um ser que exerce sua liberdade em relações de coexistência. Por outras palavras, é por meio do projeto de vida que o homem singulariza sua existência, o que se evidencia em manifestação da própria humanidade no direito.

A passagem da responsabilidade civil para o direito de danos denota um giro conceitual do fundamental da obrigação de indenizar, calcado na culpa e no ato ilícito, para à pessoa vitimada e o dano injusto. Neste contexto, surgem novos danos, dentre os quais o dano ao projeto de vida. Trata-se do resultado de um aumento das hipóteses de danos jurisprudencialmente reconhecidos, em razão da cláusula de abertura dos direitos da personalidade. Há, contudo, uma crítica que parte da doutrina atribui a este fenômeno, atentando para uma expansão desmedida ou infinita dos limites de ressarcimento dos danos. No atual estágio da doutrina, semelhante postura não aponta para a necessidade de freios para caracterização de novos danos, mas para sua correta classificação, em face de uma ampliação da concepção de dano moral.

Em atenção a um sistema clássico de responsabilidade civil ancorado em valores do liberalismo, os danos são tradicionalmente classificados em patrimoniais e extrapatrimoniais. Ultrapassando os obstáculos do pretium doloris, a compensação do dano moral encontra-se 
assentada no direito brasileiro. Todavia, o dano moral é estruturado na doutrina civilista por exclusão ao dano patrimonial (concepção negativa) ou em razão dos efeitos da lesão e sua repercussão sobre o lesado (concepção positiva). Por outras palavras, ele é definido por outros elementos que não o do ente lesado, não pontuando no centro de sua compreensão a pessoa humana. Em razão deste fato o dano moral identifica-se com o dano extrapatrimonial, absorvendo o dano ao projeto de vida.

Com vistas a reconhecer a autonomia do dano ao projeto de vida em face do dano moral, o presente trabalho seguiu duas direções: (i) a caracterização do projeto de vida em seu núcleo e (ii) sua caracterização como dano à pessoa. Em relação à primeira, entende-se que o projeto de vida é um componente do direito fundamental à liberdade da pessoa, de tal maneira que os danos que impeçam ou dificultem o livre desenvolvimento da personalidade na existência projetada do indivíduo caracterizam o dano ao projeto de vida. Em relação à segunda, depositase na classificação dos danos, formulada por Carlos Fernández Sessarego, a natureza do que denomina "dano à liberdade fenomênica da pessoa humana". Em conformidade com a distinção entre dano à pessoa e dano às coisas, advoga-se que ele se caracteriza como espécie de danos à pessoa.

Tal natureza é ensaiada pela doutrina brasileira, compreendendo-se o dano ao projeto de vida como distinto do dano moral. Trata-se do resultado do personalismo impresso ao direito dos danos pela doutrina de Carlos Fernández Sessarego. No Brasil, esse personalismo é traduzido pela primazia das situações existenciais sobre as patrimoniais, na perspectiva civil-constitucional que decorre da Constituição de 1988, em respeito ao princípio constitucional da proteção e dignidade da pessoa humana.

\section{REFERÊNCIAS}

BURGOS, Osvaldo R. Daños al proyecto de vida. Buenos Aires: Astrea, 2012.

CAPELO DE SOUSA, Rabindranath V. A.. O direito geral de personalidade. Coimbra: Coimbra Editora, 2011.

CAVALIERI FILHO, Sérgio. Programa de responsabilidade civil. 10. ed. São Paulo: Atlas, 2012.

COMANDUCCI, Paolo. Formas de (neo)constitucionalismo: un análisis metateórico. In: CARBONELL, Miguel. Neoconstitucionalismo(s) Madrid: Trotta, 2003, p. 75-98. dao.pdf> Acesso em: 21 dez. 2014.

DIAS, José de Aguiar. Da responsabilidade civil. 11. ed. Rio de Janeiro: Renovar, 2006. 
DUMONT, Louis. O individualismo: uma perspectiva antropológica da ideologia modema. Rio de Janeiro: Rocco, 2000.

DWORKIN, Ronald. Justice for hedgehogs. Cambridge: Harvard University Press, 2011.

FACHIN, Luiz Edson. Estatuto jurídico do patrimônio mínimo. 2 ed. Rio de Janeiro: Renovar, 2006.

FROTA, Hindemberg Alves. O Fundamento Filosófico do Dano Existencial. Disponível em: $\quad<$ http://tematicasjuridicas.wordpress.com/2011/11/02/dano-existencial-fundamentofilosofico> Acesso em: 07/10/ 2012.

GALDÓS, Jorge Mario. Hay daño al proyecto de vida? Disponível em: <http://www.cmfbsas.org.ar/archivos/13_RP6-09-Hay\%20Dano\%20Proy\%20Vida_.pdf> Acesso em: 14 abr. 2014.

GOMES, Orlando. A crise do Direito. São Paulo: Max Limonad, 1955.

Tendências modemas da reparação de danos. In. Estudos em homenagem ao Professor Silvio Rodrigues. Rio de Janeiro: Forense, 1980.

HEIDEGGER, Martin. Ser e tempo: parte I. 15 ed. Petrópolis: Vozes, 2005.

IGLESIAS, Sergio. Responsabilidade civil por danos à personalidade. Barueri: Manole, 2002 .

ITURRASPE, Jorge Mosset. El daño a la persona (como culminación de una larga evolución), Revista de Derecho de Daños, n. 3, 7-18.

LORENZETTI, Ricardo Luis. Fundamentos do direito privado. São Paulo: Revista dos Tribunais, 1998.

LUDWIG, Marcos de Campos. O direito ao livre desenvolvimento da personalidade na Alemanha e possibilidades de sua aplicação no direito brasileiro. MARTINS-COSTA, Judith (org.). A reconstrução do direito privado. São Paulo: Revista dos Tribunais, 2002, p. 264305 .

MAGNUS DE MARCO, Cristhian; DE CASTRO, Matheus Felipe. As dimensões e perspectivas do direito fundamental ao livre desenvolvimento da personalidade. Prisma jurídico, v. 12, n. 1, enero-junio, PP. 13-49 (esta página é a 42). Universidade Nove de Julho. São Paulo. Disponível em: WWW.redallyc.org. Acesso em: 14 de abril de 2014.

MARRAFON, Marco Aurélio. Hermenêutica e sistema constitucional: a decisão judicial entre o sentido da estrutura e a estrutura do sentido. Florianópolis: Habitus, 2008.

MARTINS-COSTA, Judith. Comentários ao novo Código Civil. Do inadimplemento das obrigações (Coord. Sálvio de Figueiredo Teixeira) v. V, tomo II (arts. 389 a 420). Rio de Janeiro: Forense, 2004.

Os danos à pessoa e a natureza de sua reparação. In: A reconstrução do direito privado. São Paulo: Revista dos Tribunais, 2002. 408-446. 
MORAES, Maria Celina Bodin de. O conceito de dignidade humana: substrato axiológico e conteúdo normativo. In: SARLET, Ivo Wolfgang (Org.). Constituição, Direitos Fundamentais e Direito Privado. Porto Alegre: Livraria do Advogado, 2003.

Danos à pessoa humana: uma leitura civil-constitucional dos danos morais. Rio de Janeiro: Renovar, 2003.

OLIVEIRA, José Lamartine Corrêa. MUNIZ, Francisco José Ferreira. O Estado de direito e os direitos da personalidade. Tese apresentada à VII Conferência Nacional da Ordem dos Advogados do Brasil.

PERLINGIERI, Pietro. Perfis do direito civil. 3 ed. Rio de Janeiro: Renovar, 2007.

PIANOVSKI RUZYK, Carlos Eduardo. Comentários ao Acórdão proferido no REsp 1.096.325/SP: O "caso das pílulas de farinha" como exemplo da construção jurisprudencial de um "direito de danos" e da violação da liberdade positiva como "dano à pessoa". Disponível em: $<$ http://fachinadvogados.com.br/artigos/Comenta\%CC\%81rios\%20ao\%20Acor

PICAZO, Luis Diez. Derecho de daños. Madrid: Civitas Ediciones, 1999.

POPP, Carlyle; PARODI, Ana Cecília. A concepção pós-moderna de dano: releitura a partir do conceito constitucionalizado de patrimônio. In: GUNTHER, Luiz Eduaro; CARNEIRO, Maria Francisca. (Coord.) Dano moral e direitos fundamentais: uma abordagem multidisciplinar. Curitiba: Juruá, 2013.

SCHREIBER, Anderson. Direitos da personalidade. 2 ed. São Paulo: Atlas, 2013.

Novos paradigmas da responsabilidade civil. 5 ed. São Paulo: Atlas, 2013.

SESSAREGO, Carlos Fernandez. Apuntes acerca del daño a la persona. El articulo ha sido publicado en el libro "La persona humana", dirigido por Guillermo A. Borda, Editora "La Ley", Buenos Aires, 2001. Disponível em <http://dike.pucp.edu.pe/bibliotecadeautor _carlos_fernandez_cesareo/articulos/ba_fs_4.PDF>. p. 16. Acesso em 01/set/2013.

Derecho a la identidad personal. Buenos Aires: Astrea, 1992.

Derecho a la identidad personal. Buenos Aires: Astrea, 1992.

. Deslinde conceptual entre "daño a la persona", "daño al proyecto de vida" y "daño moral". Disponível em: <http://dike.pucp.edu.pe/ bibliotecadeautor_carlos_fernandez_cesareo/articulos/ba_fs_6.PDF > Acesso em 30 dez. 2014.

El "proyecto de vida", merece protección jurídica? Disponível em: $\overline{\mathrm{http}}$ ://www.personaedanno.it/danni-non-patrimoniali-disciplina/el-proyecto-de-vida- mereceproteccion-jurid ica-carlos-fernandez-sessare go> Acesso em: 14 abr. 2014.

El daño al proyecto de vida en una reciente sentencia de la Corte Interamericana de Derechos Humanos. Revista de Responsabilidad Civil y Seguros, ed. "La Ley", Buenos Aires, año 1999. 
_. Que és ser `persona`para el derecho? Derecho PUC, $\mathrm{n}^{\circ}$ 53, Universidad católica, 2002. p. $33 . \quad$ Disponível em: < http://dike.pucp.edu.pe/bibliotecadeautor_carlos_fernandez_cesareo/articulos/ba_fs_13.PDF> Acesso em: 14 abr. 2014.

SICHES, Luis Recaséns. Vida humana, sociedad y derecho: fundamentación de la filosofia del derecho. México: Fondo de Cultura Económica, 1939.

SILVA, Clóvis Virgílo do Couto. O conceito de dano no direito brasileiro e comparado. In: FRADERA, Vera Maria Jacob de. (org.). O direito privado brasileiro na visão de Clóvis do Couto e Silva. Porto Alegre: Livraria do Advogado, 1997.

SILVA, Virgilio Afonso da. O conteúdo essencial dos direitos fundamentais e a eficácia das normas constitucionais. Revista de Direito do Estado. Ano. 1. N. 4. Out/dez 2006. p. 23-51.

SZANIAWSKI, Elimar. Direitos da personalidade e sua tutela. São Paulo: RT, 1993.

VALLE, Augustin Basave F. del. Filosofia do homem: fundamentos de antroposofia metafísica. São Paulo: Convívio, 1975.

WESTERMANN, Harry. Código civil alemão: parte geral. Trad. FURQUIM, Luiz Dória. Porto Alegre: Sérgio Antonio Fabris, 1991.

WOLKMER, Antônio Carlos. Pluralismo, justiça e legitimidade dos novos direitos. Revista Sequência, Florianópolis, n. 54, p. 95-106, jul. 2007. 